\title{
Studi Tentang Teknik Komunikasi Orangtua Dalam Pengembangan Kemandirian Anak Usia 5-6 Tahun Di Tk Salsa Kecamatan Percut Sei Tuan
}

\author{
Rizki Winitri ${ }^{1}$, Edward Purba ${ }^{2}$ \\ Fakultas Ilmu Pendidikan \\ Universitas Negeri Medan \\ Jln. Willem Iskandar Psr V Medan Estate \\ E-mail : winitririzki@yahoo.co.id
}

\begin{abstract}
Abstrak. Permasalahan dalam penelitian ini adalah teknik komunikasi yang diterapkan orangtua kurang sesuai terhadap anak sehingga mempengaruhi kemandirian anak, kurangnya kepercayaan orangtua terhadap kemampuan anak, dan saat memberikan instruksi, orangtua tidak memperhatikan apakah anak sudah mengerti maksud dari instruksi tersebut atau belum, serta kurangnya pemahaman orangtua tentang perannya dalam mengembangkan kemandirian anak. Penelitian ini bertujuan untuk mengetahui teknik komunikasi yang digunakan orangtua dalam mengembangkan kemandirian anak usia 5-6 tahun. Dalam penelitian ini sumber data penelitian menggunakan teknik purposive sampling. Subjek dalam penelitian ini adalah 5 orangtua yang anaknya sudah mandiri berusia 5-6 tahun.

Jenis penelitian ini adalah penelitian studi kasus dan analisis datanya menggunakan pendekatan kualitatif deskriptif. Variabel bebas adalah teknik komunikasi orangtua sedangkan variabel terikat adalah pengembangan kemandirian anak. Instrumen pengumpulan data adalah wawancara terstruktur. Data dianalisis dengan cara pengumpulan data, reduksi data, penyajian data, penarikan kesimpulan dan verifikasi.

Hasil penelitian menunjukkan bahwa teknik yang digunakan orangtua dalam mengembangkan kemandirian anak adalah dengan menggunakan teknik komunikasi yang bersifat empati, responsif, adanya pesan positif, terbuka dan terpercaya, mendengarkan secara aktif, adanya pesan optimistik, komunikasi proporsional dan tidak adanya sikap menghakimi
\end{abstract}

Kata Kunci: teknik komunikasi, kemandirian anak

\section{PENDAHULUAN}

Peran orangtua sangatlah diperlukan untuk membantu anak menumbuhkan perilaku yang mandiri. Komunikasi antara orangtua dan anak akan menjadi jembatan agar anak bisa yakin bahwa dirinya bisa mandiri. Orangtua harus memberikan kesempatan kepada anak untuk melakukan segala sesuatu dengan sendiri tanpa perlu merasa khawatir kepada anaknya dengan memberikan sikap positif kepada anak, seperti memuji dan mendukung usaha atau aktifitas yang di lakukan anak dalam kegiatannya. Misalnya, orangtua mengajak anak untuk ke kamar mandi saat anak hendak buang air kecil dan ketika malam hari sebelum anak tidur, orangtua juga mengajak anak ke kamar mandi untuk buang air kecil. Untuk pertama kali orangtua harus menemani si anak ke kamar mandi, namun orangtua juga harus memberikan kesempatan kepada anak untuk melakukannya sendiri dan orangtua hanya mengawasi anak agar si anak mulai terbiasa untuk mandiri. Jika anak sudah terbiasa ke kamar mandi sendiri, anak akan terbiasa juga ketika berada di luar rumah misalnya saja ketika anak disekolah. 
Mandiri merupakan kemampuan seseorang untuk melakukan kegiatan atau tugas-tugasnya sendiri tanpa adanya campur tangan dari orang lain. Pernyataan ini sejalan dengan pengertian yang ada di dalam Kamus Besar Bahasa Indonesia (KBBI), mandiri diartikan sebagai keadaaan yang dapat menjadikan individu berdiri sendiri, tidak tergantung pada orang lain. Menurut Wibowo (2012 : 72) Mandiri adalah sikap dan perilaku yang tidak mudah tergantung pada orang lain dalam menyelesaikan tugas-tugas.

Kemandirian sendiri merupakan hal atau keadaan dapat berdiri sendiri tanpa bergantung pada orang lain. Pengertian tersebut selaras dengan pendapat Subroto (dalam Novan 2013: 27-28) yang mengartikan kemandirian sebagai kemampuan anak untuk melakukan aktivitas sendiri atau mampu berdiri sendiri dalam berbagai hal. Montessori (2008 : 273274) menambahkan bahwa kemandirian adalah kemampuan untuk melakukan sesuatu demi dirinya sendiri. Manusia meraih kemandiriannya dengan melakukan upaya agar mampu melakukan sesuatu tanpa bantuan dari siapapun sehingga kemandirian bagi anak harus diraih secara langsung. Pernyataan Montessori tersebut diperkuat oleh Kristiyani (dalam Tim Pustaka Familia, 2006: 32) kemandirian dapat diartikan sebagai suatu kemampuan untuk memikirkan, merasakan, serta melakukan sesuatu sendiri atau tidak tergantung pada orang lain.

Komunikasi yang baik antara orangtua dan anak sangatlah penting, karena jika komunikasi antara orangtua dan anak sudah baik maka orangtua pun dapat dengan mudah untuk mengembangkan kemandirian anak. Komunikasi yang baik memerlukan waktu yang tepat, dimana orangtua dan anak terlibat percakapan yang aktif dan menyenangkan. Setiap ada kesempatan, manfaatkan momen tersebut untuk mengajak anak bicara. Bicara di sini tidak sekedar basa-basi menanyakan apa kabarnya hari ini. Akan tetapi, menyelami perasaan senang, sedih, marah, maupun keluh kesah anak. Jika sudah terbangun komunikasi yang dapat membuat orangtua dan anak lebih dekat akan memudahkan orangtua untuk membantu anak mengembangkan kemandirian anak. Oleh karena itu, komunikasi antara orangtua dan anak sangatlah diperlukan karena jika komunikasi yang kurang baik antara orangtua dan anak, bisa jadi anak malah tidak terurus. Ditambah lagi jika orangtuanya yang memiliki kesibukan di luar rumah yang menyebabkan berkurangnya waktu bersama si anak. Ada juga orangtua yang selalu melarang anak untuk melakukan sesuatu. Hal tersebut dapat menghambat perkembangan kemandirian anak. Namun, apabila orangtua memberikan kesempatan kepada anak untuk melakukannya sendiri dengan pengawasan orangtua maka akan lebih baik lagi hasilnya.

Kemandirian merupakan kemampuan yang disesuaikan dengan tugas perkembangannya, seperti belajar berjalan, belajar makan, berlatih berbicara, koordinasi tubuh, kontak perasaan dengan lingkungan, interaksi dengan orang lain, pembentukan pengertian serta belajar moral. Jika anak usia dini sudah mampu melakukan tugas-tugas perkembangannya, mereka sudah bisa dikatakan mandiri.

Membentuk kemandirian pada anak sejak usia dini sangatlah penting. Kemandirian akan mendukung anak belajar memahami pilihan perilaku beserta resiko yang harus dipertanggungjawabkan. Anak yang tidak mandiri cenderung tidak percaya diri dan tidak mampu mengambil suatu keputusan dengan baik. Selain itu, anak usia dini yang tidak mandiri akan tergantung dengan orang lain. Dalam persiapan berangkat sekolah misalnya, anak selalu ingin dimandikan orang lain, dibantu berpakaian, minta disuapi, disiapkan buku dan peralatan sekolah oleh orang lain, termasuk harus selalu diantar ke sekolah dan ditunggui selama belajar di kelas. Ketika berada di rumah, anak mau belajar jika semua 
dilayani. Misalnya, anak akan menyuruh orang lain untuk mengambilkan pensil, buku, serutan, dan sebagainya.

Komunikasi positif dalam keluarga menurut Ramadhani (2008: 135) adalah komunikasi yang dilakukan untuk mendorong setiap anggota keluarga agar dapat berkembang secara optimal, baik secara fisik maupun psikis, melalui komunikasi yang empati, responsif, mengandung pesan positif, terbuka dan terpercaya, mendengarkan secara aktif, mendorong optimisme yang proporsional dan tidak menghakimi

Berdasarkan observasi yang dilakukan penulis di TK SALSA pada usia 5-6 tahun, penulis masih menemukan masalah yaitu apabila anak berangkat sekolah, anak meminta orangtuanya untuk mengantarnya sampai ke dalam kelas bahkan ada orangtua yang menunggu anaknya sampai pulang sekolah. Jika anak tersebut ditinggal oleh orangtuanya anak tersebut akan menangis sejadi-jadinya, hal ini membuat orangtua tidak tega untuk meninggalkannya. Masalah lain yang ditemukan adalah ada anak yang tidak berani ke kamar mandi sendirian, anak tersebut selalu minta ditemani oleh guru jika ingin ke kamar mandi. Masalah lain adalah saat belajar mengajar berlangsung, ada anak yang selalu minta didampingi jika mengerjakan tugasnya padahal anak tersebut bisa mengerjakannya sendiri namun bila tidak ada yang mendampinginya dia akan berhenti mengerjakan tugasnya. Namun ada juga anak yang selalu mengerjakan tugasnya cepat selesai dibanding temannya yang lain tanpa dibantu guru. Pada saat anak mau makan bersama, ada anak yang tidak mau makan sendiri dan harus disuapin oleh guru. Ketika ditelusui ternyata anak tersebut memang dibiasakan jika berada dirumah anak tersebut selalu disuapin orangtuanya. Saat orangtuanya ditanya kenapa masih menyuapi anaknya, orangtua tersebut mengatakan bahwa jika si anak makan sendiri akan mengotori pakaian si anak dan makanannya malah dijadikan mainan. Hal tersebut membuat orangtua menjadi marah dan mengambil makanan si anak dan menyuapinya. Teknik komunikasi yang dilakukan orangtua belum tepat untuk mengembangkan kemandirian anak karena orangtua tidak memberikan kesempatan kepada anak untuk melakukan sesuatu sendiri. Dari berbagai permasalahan yang telah diuraikan, ternyata masih banyak orangtua yang kurang memahami perannya dalam mengembangkan kemandirian anak. Orangtua masih belum percaya dengan kemampuan anaknya, oleh karena itu orangtua melarang anak untuk melakukan aktivitas sendiri.

\section{METODOLOGI PENELITIAN}

Jenis Penelitian ini berupa penelitian dengan metode atau pendekatan studi kasus (case study). Penelitian ini memusatkan diri secara intensif pada satu obyek tertentu yang mempelajarinya sebagai suatu kasus. Analisis data dalam penelitian ini adalah kualitatif deskriptif. Putra \& Dwilestari (2013: 70-71) "Oleh karena yang diteliti adalah apa yang dilakukan dan dikatakan oleh para pelaku, proses yang sedang berlangsung dan berbagai aktivitas lain dalam konteks alamiah, maka peneliti mesti mendeskripsikan atau menggambarkan segala sesuatu yang dihindarinya secara lengkap, rinci, dan mendalam". Dalam penelitian ini sumber data penelitian menggunakan teknik "purposive sampling". Menurut Sugiono (2009: 124) Purposive sampling adalah teknik penentuan sampel dengan pertimbangan tertentu. Subjek penelitian ini adalah orangtua dari 5 anak PAUD yang sudah mandiri berusia 5-6 tahun di TK SALSA

Dalam rangka mengumpulkan data, peneliti menggunakan teknik wawancara terstruktur. Menurut Sugiyono (2013-233) wawancara terstruktur digunakan sebagai teknik pengumpulan data, bila peneliti atau pengumpul data telah mengetahui dengan pasti tentang informasi apa yang akan diperoleh. Dengan wawancara terstruktur ini setiap 
responden diberi pertanyaan yang sama, dan pengumpul data mencatatnya. Wawancara ini berpedoman berdasarkan kisi-kisi pengumpulan data. Hal ini bertujuan untuk mendapatkan informasi tentang teknik komunikasi orangtua dalam pengembangan kemandirian anak usia 5-6 tahun di TK SALSA. Pedoman yang disusun sangat diperlukan dalam proses berjalannya wawancara sehingga wawancara tetap berada dalam konteks fokus permasalahan. Teknik ini memberikan kesempatan pada peneliti untuk mempertanyakan secara langsung kepada responden.

Tabel 1. Kisi - Kisi Pedoman Wawancara

\begin{tabular}{|c|c|c|}
\hline Variabel & Sub Variabel & $\begin{array}{l}\text { Indikator } \\
\end{array}$ \\
\hline \multirow{8}{*}{$\begin{array}{l}\text { Teknik } \\
\text { komunikasi } \\
\text { orangtua dalam } \\
\text { pengembangan } \\
\text { kemandirian } \\
\text { anak }\end{array}$} & Empati & $\begin{array}{l}\text { Orangtua berkomunikasi dengan memahami } \\
\text { tentang perasaan, kebutuhan,dan emosi yang } \\
\text { dirasakan anak }\end{array}$ \\
\hline & Responsif & $\begin{array}{l}\text { Orangtua berkomunikasi memberikan } \\
\text { tanggapan (respon) terhadap anak }\end{array}$ \\
\hline & Adanya pesan positif & $\begin{array}{l}\text { Komunikasi yang terjadi antara orangtua } \\
\text { dan anak dapat membangkitkan perhatian } \\
\text { anak }\end{array}$ \\
\hline & $\begin{array}{l}\text { Terbuka dan } \\
\text { terpercaya }\end{array}$ & $\begin{array}{l}\text { Orangtua dan anak berkomunikasi secara } \\
\text { terbuka dan saling percaya }\end{array}$ \\
\hline & $\begin{array}{l}\text { Mendengarkan } \\
\text { secara aktif }\end{array}$ & $\begin{array}{l}\text { Orangtua bertindak sebagai pendengar yang } \\
\text { aktif dan berusaha memahami apa yang } \\
\text { dibicarakan anak }\end{array}$ \\
\hline & $\begin{array}{l}\text { Adanya pesan } \\
\text { optimistik }\end{array}$ & $\begin{array}{l}\text { Pesan orangtua dapat mendorong anak } \\
\text { untuk berpikir penuh harapan dan positif }\end{array}$ \\
\hline & $\begin{array}{l}\text { Komunikasi } \\
\text { proporsional }\end{array}$ & $\begin{array}{l}\text { Orangtua dapat menerima anak } \\
\text { sebagaimana adanya }\end{array}$ \\
\hline & $\begin{array}{l}\text { Tidak adanya sikap } \\
\text { menghakimi }\end{array}$ & $\begin{array}{l}\text { Saat anak melakukan kesalahan, orangtua } \\
\text { tidak langsung menyalahkan dan } \\
\text { memojokkan anak }\end{array}$ \\
\hline
\end{tabular}

\section{HASIL DAN DISKUSI}

Orangtua bersikap empati saat berkomunikasi dengan anak, orangtua memahami perasaan anak dan tahu apa yang dibutuhkan oleh anak sehingga anak dapat bersikap mandiri. Ketika berkomunikasi, orangtua bersikap responsif terhadap anak. Orangtua selalu memberikan tanggapan tentang sesuatu yang ditanyakan oleh anak. Karena orangtua selalu memberikan respon kepada anak, anak menjadi tahu apa saja yang harus diketahui jika anak melakukan kegiatan sendiri.

Adanya pesan positif yang diberikan orangtua kepada anak sehingga kemandirian anak dapat berkembang. Orangtua memberikan nasehat untuk anak ketika anak melakukan kegiatan sendiri, jadi anak dapat menghindari hal yang tidak baik. Ketika berkomunikasi dengan anak, orangtua dan anak berkomunikasi secara terbuka dan saling percaya sehingga kemandirian anak berkembang. Selama anak berkomunikasi dengan orangtua, orangtua selalu mendengarkan secara aktif tentang apa yang sedang dikatakan oleh anak. Orangtua selalu menyimak dan memahami perkataan anak sehingga anak menjadi percaya diri dalam berkomunikasi dengan orangtuanya dan orang lain. Hal tersebut dapat mengembangkan kemandirian anak.

Ketika berkomunikasi dengan anak, orangtua berkomunikasi dengan adanya pesan optimistik. Pesan yang diberikan orangtua dapat mendorong anak agar berpikir positif 
sehingga membuat anak mandiri. Komunikasi yang digunakan orangtua juga bersifat proporsional. Saat berkomunikasi, orangtua tidak melibatkan emosi dan menerima kelemahan dan kelebihan anak sehingga membuat anak merasa dihargai dan dapat mengembangkan kemandirian anak. Orangtua berkomunikasi dengan tidak bersikap menghakimi anak, saat anak melakukan kesalahan, orangtua tidak langsung menyalahkan dan memojokkan anak, tetapi orangtua memberitahu kesalahan anak, memperingatkan dan mengajarkan anak supaya lebih berhati-hati sehingga anak merasa bersalah dan mau bertanggung jawab ketika melakukan suatu kesalahan, hal ini dapat mengembangkan kemandirian anak

\section{PEMBAHASAN}

Teknik komunikasi yang digunakan orangtua dalam pengembangan kemandirian anak yaitu dengan menggunakan teknik komunikasi yang bersifat empati dan responsif. Teknik komunikasi yang digunakan oleh responden A, yaitu: responden A bersifat empati saat berkomunikasi dengan anak, setelah orangtua berempati kepada anak, orangtua juga memberikan respon saat berkomunikasi dengan anak. Orangtua juga berkomunikasi dengan adanya pesan positif kepada anak agar membangkitkan perhatian anak. Orangtua berkomunikasi secara terbuka dan saling percaya serta mendengarkan secara aktif ketika anak sedang bercerita. Orangtua juga memberikan pesan yang optimistik agar anak dapat berpikir penuh harapan dan positif, sehingga komunikasi yang terjalin dapat proporsional. Saat anak melakukan kesalahan, orangtua akan marah tetapi orangtua tidak langsung menghukum dan memojokkan anak.

Komunikasi yang terjalin antara responden B dan anak adalah orangtua berempati dengan anak dengan cara memperhatikan dan mengawasi anak disegala bidang. Orangtua merespon anak dengan menjawab semua pertanyaan anak, dan orangtua juga memberikan nasehat yang positif kepada anak. Orangtua dan anak berkomunikasi secara terbuka dan saling percaya. Orangtua berupaya mendengarkan secara aktif saat anak bercerita dan memberikan pesan yang optimistik. Orantua berupaya agar dapat berkomunikasi secara proporsional dan tidak melakukan sikap yang menghakimi kepada anak.

Responden $\mathrm{C}$ sering berkomunikasi dengan anak, orangtua menunjukkan rasa empatinya dengan memenuhi semua kebutuhan anak dan memperhatikan perilaku anak. Untuk menanggapi perasaan anak, orangtua sering melakukan percakapan dengan anak. Orangtua juga memberi pesan atau nasehat kepada anak, agar anak dan orangtua berkomunikasi secara terbuka dan saling percaya. Orangtua berusaha menunjukkan komuikasi yang proporsional agar perkembangan kemandirian anak dapat berkembang maksimal. Orangtua juga bersikap bijak jika anak melakukan kesalahan, orangtua tidak langsung menghakimi dan memojokkan anak.

Komunikasi yang digunakan responden $\mathrm{D}$ juga tidak jauh berbeda dengan yang digunakan resonden a, b, c. Akan tetapi responden D, lebih memberikan keluwesan kepada anak untuk bertindak sendiri. Orangtua mempercayakan segala sesuatu kepada anak. Dan anak juga sangat terbuka jika sedang berkomunikasi dengan orangtua.

Responden E menggunakan komunikasi yang bersifat empati dan responsif. Orangtua selalu mendengarkan cerita anak dan memberi tanggapan setelah anak bercerita. Anak semakin terbuka dan percaya kepada orangtua, hal ini dimanfaatkan orangtua untuk memberikan nasehat yang positif dan optimis agar komunikasi yang terjalin dapat proporsional sesuai tempatnya. Orangtua juga melakukan variasi jika anak merasa bosan 
dan malas, orangtua selalu memotivasi dan memberikan semangat kepada anak. Jika anak melakukan kesalahan, orangtua awalnya marah dan memberikan hukuman kepada anak (bukan hukuman fisik).

Teknik komunikasi yang digunakan oleh responden a, b, c, d, dan e yaitu dengan menggunakan teknik komunikasi yang bersifat empati, responsif, adanya pesan positif, terbuka dan terpercaya, mendengarkan secara aktif, adanya pesan optimistik, komunikasi proporsional, dan tidak adanya sikap menghakimi. Teknik tersebut diperkuat dengan teknik komunikasi menurut Ramadhani (2008:135) yaitu teknik komunikasi positif adalah teknik komunikasi yang dilakukan untuk mendorong setiap anggota keluarga agar dapat berkembang secara optimal, baik secara fisik maupun psikis, melalui komunikasi yang bersifat empati, responsif, adanya pesan positif, terbuka dan terpercaya, mendengarkan secara aktif, adanya pesan optimistik, komunikasi proporsional, dan tidak adanya sikap menghakimi

\section{SIMPULAN}

Berdasarkan hasil penelitian dapat disimpulkan bahwa teknik komunikasi yang digunakan orangtua dalam mengembangkan kemandirian anak adalah responden A, B, C, D dan E menggunakan komunikasi yang bersifat empati, responsif, adanya pesan positif, terbuka dan terpercaya, mendengarkan secara aktif, adanya pesan optimistik, komunikasi proporsional, dan tidak adanya sikap menghakimi. Tetapi masing-masing responden melakukan teknik tersebut dengan menggunakan pendekatan yang berbeda. Akan tetapi, masing-masing responden tetap menggunakan teknik komunikasi yang bersifat empati dan responsif dalam melakukan komunikasi kepada anak

Berdasarkan hasil penelitian ini, maka saran yang dapat peneliti berikan adalah sebagai berikut:

1. Untuk mengembangkan kemandirian anak orangtua dianjurkan menggunakan teknik komunikasi yang bersifat empati, responsif, adanya pesan positif, terbuka dan terpercaya, mendengarkan secara aktif, adanya pesan optimistik, komunikasi proporsional dan tidak adanya sikap menghakimi.

2. Saat anak mulai berkomunikasi dengan orangtua, hendaknya orangtua lebih memperhatikan bahasa tubuh anak, agar orangtua tahu apa yang sebenarnya dibutuhkan anak sehingga komunikasi yang terjalin semakin maksimal.

3. Jika orangtua ingin membangun komunikasi yang baik dengan anak, orangtua juga harus menghindari kekerasan secara verbal ataupun non verbal, misalnya menghujat/memaki anak, mencubit anak, memukul dan sebagainya agar komunikasi yang terjalin dapat berjalan harmonis

\section{DAFTAR RUJUKAN}

Chazen, et al. 1983, Helping Your Children With Behavior Difficulties, Canberra, University Par Press

Dahlan. D. 2004. Psikologi Perkembangan Anak Dan Remaja. Bandung: Percetakan PT Remaja Rosdakarya

Desmita. 2011. Psikologi Perkembangan Peserta Didik. Bandung: PT. Remaja Rosda Karya

Fadlillah, M \& Lilif, M. 2013. Pendidikan Karakter Anak Usia Dini. Jogjakarta: Ar-Ruzz Media 
Familia, Tim Pustaka. 2006. Membuat Prioritas, Melatih Anak Mandiri. Yogyakarta: Penerbit Kanisius

Kepribadian Positif Pada Anak Melalui Komunikasi Positif. Yogyakarta: Bookmarks.

Montessori. 2008. The Absorbent Mind Pikiran yang Mudah Menyerap. Yogyakarta: Pustaka Pelajar

Muhammad, A. 2007. Komunikasi Organisasi. Jakarta: PT Bumi Aksara

Novan, A, W. 2013. Bina Karakter Anak Usia Dini: Panduan Orangtua \& Guru dalam Membentuk Kemandirian \& Kedisiplinan Anak Usia Dini. Yogyakarta: Ar Ruzz Media.

Putra, N \& Dwilestari, N. 2013. Penelitian Kualitatif PAUD. Jakarta: PT Raja Grafindo Persada

Ramadhani, S. 2008. The Art of Positive Communicating: Mengasah Potensi dan

Sjarkawi, 2006. Pembentukan Kepribadian Anak. Jakarta: Bumi Aksara

Sugiono. 2009. Metode Penelitian Pendidikan (Pendekatan Kuantitatif, Kualitatif, dan $R \& D)$. Bandung: Cv. Alfabeta

Sugiyono. 2013. Metode Penelitian Kuantitatif, Kualitatif dan R\&D. Bandung: Cv. Alfabeta

Uchjana, E.O. 2006. Ilmu Komunikasi Teori dan Praktek. Bandung: PT Remaja Rosdakarya

Wibowo, Agus. 2012. Pendidikan Karakter Usia Dini (Strategi Membangun Karakter di Usia Emas). Yogyakarta: Pustaka Pelajar. 